\title{
Renal fumour scoring systems: How useful are they?
}

\author{
Anil Kapoor, MD, FRCSC \\ Division of Urology, Department of Surgery, McMaster University, Hamilton, ON
}

See related article on page 39 .

Cite as: Can Urol Assoc J 2015;9(1-2):46-7. http://dx.doi.org/10.5489/cuaj.2740

Published online February 5, 2015.

$\mathrm{P}$ artial nephrectomy for renal tumours is a challenging surgical operation, whether performed through the traditional open surgical route, or approached laparoscopically or robotically. Any operation where there is an ablative component, with a reconstructive component, within the confines of renal ischemia with the clock ticking ("every minute counts"), can challenge any urologic surgeon's skills. There is the risk for perioperative bleeding, blood transfusion, and renal ischemia with prolonged renal hilar clamping. Postoperatively, there are risks of renal pseudo-aneurysm, peri-nephric hematoma, urine leak, kidney non-function from prolonged ischemia, residual tumour from incomplete excision, and perioperative medical morbidity.

Any tools to minimize the risk of intra-operative and postoperative complications from partial nephrectomy are welcome. There has been a proliferation of renal scoring systems, with the PADUA scoring system, RENAL scoring system, Centrality index (C-index), ${ }^{1-3}$ and recently the RTII score, ${ }^{4}$ and the CSA (contact surface area) score. ${ }^{5}$ These scoring systems attempt to objectively quantify the complexity of renal tumours in preparation for surgery. But which scoring system is better and how useful are they to the urologic surgeon?

Desantis, and colleagues ${ }^{6}$ in this issue of CUAJ tackle a comparison of the three most common renal tumour scoring systems by comparing the PADUA, RENAL and C-Index scores in a cohort of patients undergoing partial nephrectomy and correlate with postoperative complications. They have found that tumour size and tumour depth within the kidney are more predictive of complications than other

components of these scoring systems. Further, polar versus mid-kidney location of the tumour appear to have an inverse relationship to perioperative complications. Put together, this data would suggest that these current scoring systems are imperfect, and further work needs to be done to optimize their usefulness. Newer scoring systems, such as the RTII score, assess tumour depth to parenchymal thickness ratio, and the CSA score, assess tumour contact with normal parenchyma, and may be more predictive of renal surgery complexity. Of course, more study and validation is required for these newer scoring systems.

Practically, how many of us use a renal scoring system before surgery? How many of us use a "renal score" in discussion with patients? Most of us "eye-ball" the tumour and give an educated and experienced opinion on the potential complexity and difficulty of surgery. As renal scoring systems are fine-tuned, for now we can rely on the size and depth of the tumour (endophytic component) as objective measures of the complexity of surgery.

Competing interests: Dr. Kapoor is a member of the Speakers bureau for, and has received grants and honoraria from, Pfizer Oncology, GSK Oncology, Novartis Oncology and Amgen. He has also participated in clinical trials within the past 2 years with NCIC, Pfizer, GSK, Novartis and Amgen.

This paper has been peer-reviewed.

\section{References}

1. Kutikov A, Uzzo RG. The R.E.N.A.L. nephrometry score: A comprehensive standardized system for quantitating renal tumor size, location and depth. J Urol 2009;182:844-53. http://dx.doi.org/10.1016/i. juro.2009.05.035

2. Ficarra V, Novara $G$, Secco $S$, et al. Preoperative aspects and dimensions used for an anatomical (PADUA) classification of renal tumors in patients who are candidates for nephron-sparing surgery. Eur Urol 2009;56:786-93. http://dx.doi.org/10.1016/i.eururo.2009.07.040

3. Simmons MN, Ching CB, Samplaski MK, et al. Kidney tumor location measurement using the C index method. J Urol 2010;183:1708-13. http://dx.doi.org/10.1016/i.juro.2010.01.005 
4. Nisen $\mathrm{H}$, Ruutu $\mathrm{M}$, Glücker $\mathrm{E}$, et al. Renal tumor invasion index as a novel anatomical classification predicting urological complications after partial nephrectomy. Scand J Urol 2014;48:41-51. http:// dx.doi.org/10.3109/21681805.2013.797491

5. Leslie S, Gill IS, de Castro Abreu AL, et al. Renal tumor contact surface area: A novel parameter for predicting complexity and outcomes of partial nephrectomy. Eur Urol 2014; 10.1016/i.eururo.2014.03.010. Epub 19 Mar 2014
6. Desantis $D$, Lavallee $L$, Witiuk $K$, et al. The association between renal tumour scoring system components and complications of partial nephrectomy. Can Urol Assoc J 2015;9:39-45. http://dx.doi.org/10.5489/ cuai.2303

Correspondence: Dr. Anil Kapoor, G344 - McMaster Institute of Urology, 50 Charlton Ave. E, Hamilton, 0N L8N 4A6; akapoor@mcmaster.ca

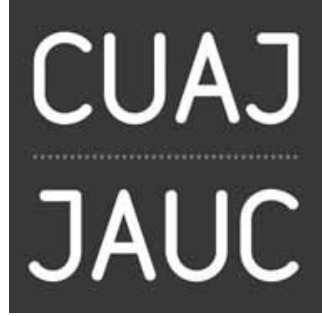

\section{CUAJ Exclusive Online Articles}

\section{Original Research}

Safety, efficacy and outcomes of the new GreenLight XPS 180W laser system compared to the GreenLight HPS 120W system for the treatment of benign prostatic hyperplasia in a prospective nonrandomized single-centre study

A. Eken, B. Soyupak, M. Acil, T. Arpaci, T. Akbas

Assessment of photoselective vaporization of prostate skills during urology objective structured clinical examinations

Y. Noureldin, M.A. Elkoushy, N. Fahmy, S. Carrier, M.M. Elhilali,

S. Andonian

Strain elastography in the characterization of renal cell carcinoma and angiomyolipoma

S. Keskin, S. Güven, Z. Keskin, H. Özbiner, Ü. Kerimoğlu, A. Yeşildağ

Factors affecting complications according to modified Clavien classification in complete supine percutaneous nephrolithotomy

S. Falahatkar, K.G. Moghaddam, E. Kazemnezhad, A. Farzan, H.B. Aval, A. Ghasemi, E. Shahab, S.S. Esmaeili, R. Motiee, S.A.M. Langroodi, M. Nemati, A. Allahkhah

\section{Case Reports}

Adult adrenal ganglioneuroblastoma: $A$ rare case report X. Ding, Y. Hou, X. Ma, H. Zhang, C. Wang, Y. Wang

Lumbar plexopathy as a complication of percutaneous nephrolithotomy in a horseshoe kidney

A.G. Lantz, R.J. Honey

\section{Case Series}

Early experience with microsurgical spermatic cord denervation for chronic orchialgia at a Canadian centre

D.J. Cassidy

Robotic radical cystectomy with intracorporeal neobladder: Initial experience and outcomes

Z.A. Butt, E. Forbes, J. Zorn J, B. Saint Martin 